1. Х.К. Гаделева, Функциональные продукты питания. Учебное пособие / Х.К. Гаделева. - М.: КноРус, 2016. - 627 с.

2. Брусника: полезные свойства [Электронный ресурс]. - URL: https://antonovsad.ru/brusnika-poleznye-svoystva-i-prostye-recepty-dlya-zdorovya-3047/

3. Польза мелиссы. Химический состав мелиссы. [Электронный ресурс]. - URL: https://g.janecraft.net/poleznye-svojstva-melissy-ximicheskij-sostav-melissy/

4. Малина: польза и вред для здоровья организма. [Электронный ресурс]. - URL: https://polzavred-edi.ru/malina-polza-i-vred-dlja-zdorovja-organizma/

5. И. М. Скурихин, В.А. Тутельян Химический состав российских пищевых продуктов: Справочник / Под ред. член-корр. МАИ, проф. И. М. Скурихина и академика РАМН, проф. В. А. Тутельяна. - М.: ДеЛи принт, 2002. -236 с.

\title{
SEARCH FOR SIGNIFICANT PARAMETERS OF HEART RATE VARIABILITY FOR ASSESSING ATHLETES FITNESS
}

\author{
Dolganov A.Yu. ${ }^{1}, \underline{\text { Osadchikova L.S. }}{ }^{1}$ \\ 1) Ural Federal University \\ E-mail: anton.dolganov@urfu.ru
}

The work conducted a search for the relationship between the parameters of heart rate variability and athletic performance. It is shown that among 64 parameters for different groups of athletes, one can distinguish those parameters that statistically significantly change during the training process.

The collection of information in sports most often pursues either a research goal, or the goal of rationalizing and optimizing pedagogical, psychophysical, biomedical control or increasing the effectiveness of training exposure. In the practice of sports schools, equipment can rarely be used to test the coordination and psychomotor abilities of athletes. At the same time, the importance of controlling readiness for coordination in situational, game, and extreme sports has been noted by many researchers.

An urgent task is to study the possibilities of assessing the current level of fitness during training. This work shows the initial stage of the study of the possibility of assessing the current level of fitness during training in a sports school. The purpose of this study is to search for the relationships between heart rate variability parameters and athletes' fitness indicators.

In the course of this work, studies were carried out with the participation of two groups of volunteer test subjects from the School of the Olympic Reserve, the women's volleyball team and the men's martial arts team. Research time period October 2018 April 2019 A total of 76 studies were conducted. 120 signals were used for processing: 60 signals in the state of functional rest and 60 signals when using the "Target" load test.

When conducting research in this work, a computer stabilizer with biological feedback "Stabilan-01-2" was used. The "Target" functional load was used in which the 
test subject on the platform fully controls the pressure center and seeks to hold it at a certain point [1].

In the work, 64 parameters of heart rate variability (HRV) signals were used, including statistical parameters, geometric parameters, spectral parameters, as well as a set of the most significant nonlinear parameters [2]. A search was made for such HRV parameters that statistically significantly change at the beginning of the school year and at the end.

It is shown that among 64 parameters of HRV for different groups of athletes, various parameters can be distinguished that statistically significantly change during the training process ( $\mathrm{p}$-value less than 0.05). At the same time, it is worth noting that the parameters for athletes from the Group of Fighters and the Group of Volleyball players are different. Such, for the Target stage, Wrestlers are statistically significant parameters associated with the Low-frequency component of HRV, and for Volleyball players are statistically significant parameters associated with the Very Low-frequency component of HRV.

1. Kublanov, V. S., Yamaliev, D. R., Dolganov, A. Y. Goncharova, E. A. Proceedings 2017 Siberian Symposium on Data Science and Engineering, SSDSE 2017, 49-54 (2017).

2. Kublanov, V. S., Dolganov, A. Y. Applied Soft Computing Journal 77, 329-343 (2019).

\title{
BENEFITS AND LIMITATIONS OF USING BIOPESTICIDES
}

\author{
Essiedu J.A. ${ }^{1}$, Adepoju F.O. ${ }^{1}$, Ivantsova M.N. ${ }^{1}$ \\ ${ }^{1)}$ Institute of Chemical Engineering, Ural Federal University \\ E-mail: asiedujustice@gmail.com
}

Agriculture entails the cultivation of plants and animals for food, biofuel, and different products for human wellbeing. Principally, plant protection, interference, and wipe-out against disease strategies use pesticides with the majority being synthesized from a chemical.

Pesticides are substances aimed at preventing and controlling pests including vectors of human or animal diseases, unacceptable species of plants and animals affecting the production, processing, and storage of agricultural products. Pesticides can be classified into two major groups based on their synthesis: Chemical pesticides and biological pesticides (biopesticides) [1].

Chemical pesticides are usually synthesized from chemical components with the purpose of regulating the growth of plants, controlling and protecting crops from plant disease, rodents, and insects by killing plant pathogens and weeds. The application of chemical pesticides on plants has generated several negative effects on human health such as acute toxicity, development of Parkinson's diseases, as well as environmental challenges including decreasing soil diversity and pollution. Due to the dangerous effects of utilizing chemical pesticides, an effective and eco-friendly method is required 